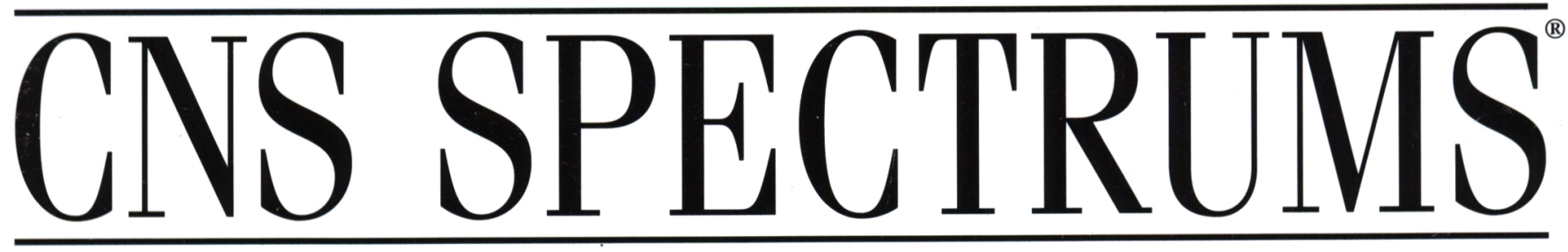

The International Journal of Neuropsychiatric Medicine

\title{
11
}

\section{Late-life Depression and Dementia}

\author{
Guest Editor-Benoit H. Mulsant, MD \\ INTRODUCTION \\ Geriatric Psychiatry: \\ Challenges and Opportunities \\ B.H. Mulsant \\ ORIGINAL RESEARCH \\ Primary Care Physicians' Attitude \\ Toward Diagnosis and Treatment \\ of Late-life Depression \\ J.S. Harman, E.L. Brown, T. Ten Have, \\ B.H. Mulsant, G. Brown, and M.L. Bruce \\ REVIEW \\ Dementia Caregiving:
}

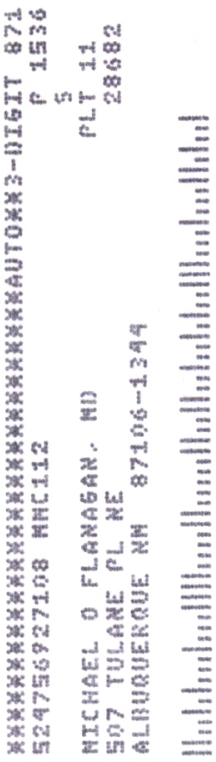

Recent Research on Negative Health Effects

and the Efficacy of Caregiver Interventions

L.M. Martire and M. Hall

REVIEW

Assessment of Behavioral and

Psychological Symptoms of Dementia

A.J. Bharucha, J. Rosen,

B.H. Mulsant, and B.G. Pollock

REVIEW

Anxiety Disorders in Late Life:

An Evolving Picture

E.J. Lenze, M.K. Shear,

B.H. Mulsant, and C.F. Reynolds III

ORIGINAL RESEARCH

The Establishment of a Brain Bank for the Study of Late-life Depression:

A Feasibility Study of Factors

Facilitating Consent

C. McFarland, R.A. Sreet, S.T. DeKosky,

P.R. Houck, B.H.Mulsant,

B.G. Pollock, and C.F. Reynolds III

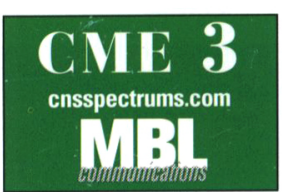

CNS Spectrums is an Index Medicus journal. 
In a teratology study in rabbils, an increased incidence of postimplantation fetal loss occurred in dams exposed to 60 300 and $1500 \mathrm{mg} / \mathrm{kg} / \mathrm{day}$, or less than approximately $1 / 4$ to 8 times the maximum human dose on a mo/ $\mathrm{m}^{2}$ basis. There are no adequate and well-controlled studies in pregnant women. Because animal reproduction studies are not always predictive of human response, this drug should be used during pregnancy only if the potential benefit justifies the potential risk to the fetus. Use in Mursing Mothers Gabapentin is secreted into human milk following oral administration. A nursed infant could be exposed to a maximum dose of approximately $1 \mathrm{mg} / \mathrm{kg} / \mathrm{day}$ of gabapentin. Because the eftect on the nursing intant is unknown, Neurontin should be used in women who are nursing only it the benetits clearly outweigh the risks. Podilatric Use Effectiveness in pediatric patients below the age of 3 years has no noen established (see CLINCAL PHARMACOLOGY, Clinical Studies). Geriatric Use Clinical studies of Neurontin dí not include sufficient numbers of subjects aged 65 and over to determine whether they responded differently from younger subjects. Other reportied clinical experience has not identitied differences in responses between the elderly and younger
patients. In general, dose selection for an elderly patient should be cautious, usually starting at the low end of the dosing patients. In general, dose selection tor an elderly patient should be cautious, usually starting at the low end of the dosing

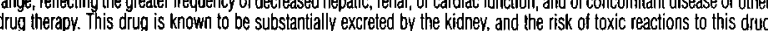
may be greater in patients with impaired renal function. Because elderly patients are more likely to have decreased ren may be greater in patients with impaired renal function. Because elderly patients are more likely to have decreased rena function, care should be taken in dose selection, and it may be usetul to monitor renat
PHARMACOLOGY, ADVERSE REACTIONS, and DOSAGE AND ADMINISTRATION sections).

\section{ADVERSE REACTIONS}

The most commonly observed adverse events associated with the use of Neurontin in combination with other antiepileptic drugs in patients > 12 years of age, not seen at an equivalent frequency among placebo-treated patients, were somnolence diziness, ataxia, faligue, and nystagmus. The most commonly observed adverse events reported with the use of Neurontin in combination with other antiepileptic drugs in pediatric patients 3 to 12 years ol age, not seen at an equal frequency among placebo-treated patients, were viral infection, fever, nausea and/or vomiting, somnolence, and hostility (see WARNinGS, Neuropsychiatric Adverse Events). Approximately $7 \%$ of the 2074 patients $>12$ years of age and approximately $7 \%$ of the 449 pedialric patients 3 to 12 years of age who received Neurontin? in premarketing clinical trials discontinued treatment because of an adverse event. The adverse events most commonly associated with withdrawal in patients $>12$ years of age

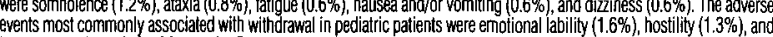
events most comminonly associated with withdrawal in pediatric patients were emotional lability $(1.6 \%)$, hostility $(1.3 \%)$, and that occurred in at least $1 \%$ of Neurontino-rtreated patients $>12$ years of age with epilepsy participating in placebo-controlleed that occurred in at least $1 \%$ of Neurontin ${ }^{\infty}$-treated patients $>12$ years of age with epilepsy participating in placebo-controlled to the patient's current antilepileptic drug therapy. Adverse events were usually mild to moderate in intensity. The prescriber should be aware that these figures obtained when Neurontin ${ }^{B}$ was added to concurrent antiepileptic drug therapy, canno be used to predict the frequency of adverse events in the course of usual medical practice where patient characteristics and other factors may differ from those prevaling during clinical situdies. Similarly, the cited frequencies cannot be directly compared with figures obtained from other clinical investigations involving different treatments, uses, or investigators. An inspection of these frequencies, however, does provide the prescribing physician with one basis to estimate the relative contribution of drug and nondrug factors to the adverse event incidences in the population studied.

TABLE 1. Treatment-Emergent Adverse Event Incidence in Controlled Add-On Trials in Patients >12 Years of Age (Events in at least $1 \%$ of Neurontin patienis and numerically more frequent than in the placebo group)

\begin{tabular}{|c|c|c|c|c|c|}
\hline $\begin{array}{l}\text { Body System/ } \\
\text { Adverse Event }\end{array}$ & $\begin{array}{c}\text { Neurontin } \\
N=543 \\
\%\end{array}$ & $\begin{array}{c}\text { Placebo } \\
\mathrm{N}=378 \\
\%\end{array}$ & $\begin{array}{l}\text { Body System/ } \\
\text { Adverse Event }\end{array}$ & $\begin{array}{c}\text { Neurontin }{ }^{\text {ma }} \\
N=543 \\
\%\end{array}$ & $\begin{array}{c}\text { Placebo }^{\mathrm{a}} \\
\mathrm{N}=378 \\
\%\end{array}$ \\
\hline \multicolumn{3}{|l|}{ Body As A Whole } & \multicolumn{3}{|c|}{ Nervous System (cont'd) } \\
\hline Fatigue & 11.0 & 5.0 & Tremor & 6.8 & 3.2 \\
\hline Weight increase & 2.9 & 1.6 & Nervousness & 2.4 & 1.9 \\
\hline Back Pain & 1.8 & 0.5 & Dysarthria & 2.4 & 0.5 \\
\hline Peripheral Edema & 1.7 & 0.5 & Amnesia & 2.2 & 0.0 \\
\hline Cardiovascular & & & Depression & 1.8 & 1.1 \\
\hline Vasodilatation & 1.1 & 0.3 & Thinking Abnormal & 1.7 & 1.3 \\
\hline Digestive System & & & Twitching & 1.3 & 0.5 \\
\hline Dyspepsia & 2.2 & 0.5 & Coordination Abnormal & 1.1 & 0.3 \\
\hline Mouth or Throat Dry & 1.7 & 0.5 & Resniratory System & & \\
\hline Constipation & 1.5 & 0.8 & Rhinitis & 4.1 & 3.7 \\
\hline Dental Abnormalities & 1.5 & 0.3 & Pharyngitis & 2.8 & 1.6 \\
\hline Increased Appetite & 1.1 & 0.8 & Coughing & 1.8 & 1.3 \\
\hline \multicolumn{3}{|c|}{ Hematologic and Lymohatic Systems } & \multicolumn{3}{|l|}{ Skin and Appendages } \\
\hline Leukopenia & 1.1 & 0.5 & 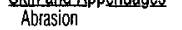 & 1.3 & 0.0 \\
\hline \multicolumn{3}{|l|}{ Musculoskeletal System } & Pruritus & 1.3 & 0.5 \\
\hline Myalgya & 2.0 & 1.9 & \multicolumn{3}{|l|}{ Urogenital System } \\
\hline Fracture & 1.1 & 0.8 & Impotence & 1.5 & 1.1 \\
\hline \multicolumn{3}{|l|}{ Nervous System } & \multicolumn{3}{|l|}{ Special Senses } \\
\hline Somnolence & 19.3 & 8.7 & Oiplopia & 5.9 & 1.9 \\
\hline Dizziness & 17.1 & 6.9 & Amblyopia ${ }^{b}$ & 4.2 & 1.1 \\
\hline Alaxia & 12.5 & 5.6 & Laboratory Deviations & & \\
\hline Nystagmus & 8.3 & 4.0 & WBC Decreased & 1.1 & 0.5 \\
\hline
\end{tabular}

Plus background antiepileptic drug therapy. "Amblyopia was often described as blurred vision.

Other events in more than $1 \%$ of patients $>12$ years of age but equally or more frequent in the placebo group included: (1) headache, viral intection, fever, nausea and/or vomiting, abdominal pain, diarrhea, convulsions, contusion, insomnia, Neurontin-treated patients, somnolence and ataxia appeared to exhibit a positive dose-response relationship. The overall incidence of adverse events and the tyoes of adverse events seen were similar among men and women treated with incidence of adverse events and he lypes of adverse enents seen we similar among men and women treated with Neurorithe other), there are insulficient data to support a statement regarding the distribution of adverse events by race. Table 2 lists treatment-emergent signs and symptoms that occurred in at least $2 \%$ of Neurontin-treated patients 3 to 12 years of age with epilepsy participating in placebo-controlled trials and were numerically more common in the Neurontin group. Adverse events were usually mild to moderate in intensity.

TABLE 2. Treatment-Emergent Adverse Event Incidence in Pediatric Patients Age 3 to 12 Years in a Controlled Add-On Trial

(Events in at least 2\% of Neurontin patients and numerically more frequent than in the placebo group)

\begin{tabular}{|c|c|c|c|c|c|}
\hline $\begin{array}{l}\text { Body System/ } \\
\text { Adverse Event }\end{array}$ & $\begin{array}{c}\begin{array}{c}\text { Neurontin } \\
\mathrm{N}=119 \\
\%\end{array} \\
\%\end{array}$ & $\begin{array}{c}\text { Placeboa } \\
N=128 \\
\%\end{array}$ & $\begin{array}{l}\text { Body System/ } \\
\text { Adverse Event }\end{array}$ & $\begin{array}{c}\text { Neurontin }^{\mathrm{a}} \\
\mathrm{N}=119 \\
\%\end{array}$ & $\begin{array}{c}\text { Placebo }{ }^{a} \\
N=128 \\
\%\end{array}$ \\
\hline \multicolumn{6}{|l|}{ Body As A Whole } \\
\hline Viral Infection & 10.9 & 3.1 & Somnolence & 8.4 & 4.7 \\
\hline Fever & 10.1 & 3.1 & $\begin{array}{l}\text { Hostility } \\
\text { Hed }\end{array}$ & 7.6 & 2.3 \\
\hline Weight increase & 3.4 & 0.8 & Emotional Lability & 4.2 & 1.6 \\
\hline Fatigue & 3.4 & 1.6 & Dizziness & 2.5 & 1.6 \\
\hline \multirow{3}{*}{$\frac{\text { Digestive System }}{\text { Nausea and/or Vomiting }}$} & & & Hyperkinesia & 2.5 & 0.8 \\
\hline & 8.4 & 7.0 & Respiratory System & & \\
\hline & & & $\begin{array}{l}\text { Bronchitis } \\
\text { Respiratory Intection }\end{array}$ & $\begin{array}{l}3.4 \\
2.5\end{array}$ & $\begin{array}{l}0.8 \\
0.8\end{array}$ \\
\hline
\end{tabular}

\section{a Plus background antiepileptic drug therapy.}

Other events in more than $2 \%$ of pediatric patients 3 to 12 years of age but equally or more frequent in the placebo group included: pharyngitis, upper respiratory infection, headache, rhinitis, convulsions, diarrhea, anorexia, coughing, and otitis media

Other Adverse Events Observed During All Clinical Trials Neurontin thas been administered to 2074 patients Other Adverse Events Observed During All Clinieal Trials Neurontin has been administered to 2074 patients
$>12$ years of age during all clinical trials, only some of which were placebo-controlled. During these trials, all adverse events were recorded by the clinical investigators using terminology of their own choosing. To provide a meaningtul estimale of the proportion of individuals having adverse events, similar types of events were grouped into a smaller number

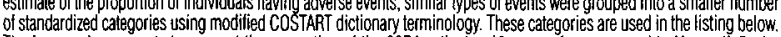
The frequenciesegries using moditied COSTART dictionary terminology. These categories are used in the listing below. (a) not reasonably associated with the use of the drug. Events are further classified within body system categories and enumerated in order of decreasing frequency using the following definitions: frequent adverse events are detined as those occurring in at leas in fewer than $1 / 1000$ patients. Body As A Whole: Frequent asthenia, malaise, face edema; Intrequent: allergy, generalized edema, weight decrease, chill; Rare: stranige feelings, lassitude, alcohol intolerance, hangover effect. Cardiovascular System: Frequent: hypertension; Infrequent: hypotension, angina pectoris, peripheral vascular disorder, paipitation, lachycardia, migraine, murmul; Rare: atrial tibrillation, hear lallure, thromboghiebitis, deep thrombophlebitis, myocardial infarcion, cerebrovascular accident, pumonary thrombosis, ventiticuiar extrasystoles, bradycardia, premature atrial contraction, per cardial Digeslivo System. Frequen a a ncea pancrea:tilis, peptic ulcer, colitis, olsters in mouth, looth discolor, per eche, sativary gland enlarged, lip hemorrhage,

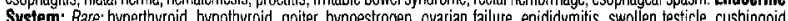

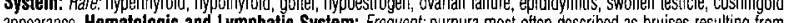
appearace. Hento

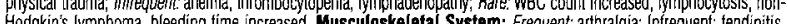

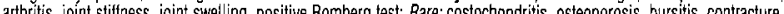
arthis, Jint silness, oint le

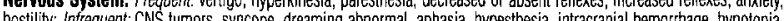
hosthy, hequent. CNS lonis, sycope, dreaning abnormal, aphasia, hypesthesia, intractanial hemorthage, hypotonia, position sense sublor poston ench

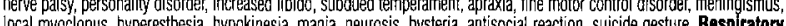

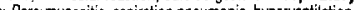

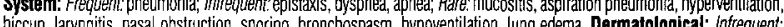
alopecia, eczema, dry skin, increased sweating, uticaria, hirsutism, sebornea, cyst, herpes simplex: Rare: herpes zoster, skin discolor, skin papules, photosensitive reaction, leq uicer, scalp seborrhea psoriasis, desquamation, maceration, skin nodules, subcutanenus nod ute melanosis, skin necrosis tocal swelling Urogenital System: Infrequen: hematuria, dysuria, urination trequency, cysititis, urinary retention, urinary incontinence, vaginal hemorrhage, amenorhea, dysmenorrhea, menorrhagia, breast cancer unable to climax ejaculation abnomal: Rare: kioney pain, leukorrhea, pruritus genital, renal stone, acute renal tailure, anuria, glycosuria, nephrosis, nocturia, pyuria, urination urgency, vaginal pain, breast pain, testicle pain. Special Senses: Frecuent: abnormal vision; Intrequent calaract, con iunctivitis, eves dry eye pain, visual field detect, photophobia, bilateral or unilateral stosis, eve hemorrhace, hordeolum, hearing loss, earache, tinnitus, inner ear infection, otitis, taste loss, unusual taste, eve twitching, ear fullhess; Rare eye itching, abnormal accommodation, perforated ear drum, sensitivity to noise, eye focusing problem, watery eyes, retinopathy, glaucoma, iritis, corneal disorders, lacrimal dysfunction, degenerative eye changes, blindness, retinal degeneration, micsis, chorioretinitis, strabismus, eustachian tube dysfunction, labyrinthitis, otitis externa, odd smell. Adverse events occurring during clinical trials in 449 pediatric patients 3 to 12 years of age treated with gabapentin that were not reported in adjunctive trials in adults are: Body As A Whole: delyydration, infectious mononucleosis. Digestive System: hepatitis. Hemic and Lymphatic System: coagulation delect. Nervous System: aura disappeared, occipital neuralgia. Psychobiologic Function: sleepwalking. Respiratory System: pseudocroup, hoarseness. Postmarketing and olher Experience In addition to the adverse experiences reported during clinical testing of Neurontinn the following adverse experiences have been reported in patients receiving makketed Neurontine. These adverse experiences listing is al phabetized: angioederna, blood glucose fluctuation, erythema multiforme, elevated liver function tests, fever, hyponatremia, jaundice, Stevens-Johnson syndrome.

DRUG ABUSE AND DEPEHDENCE

The abuse and dependence potential of Neurontins has not been evaluated in human studies. OVERDOSAGE

A lethal dose of gabapentin was not identified in mice and rats receiving single oral doses as high as $8000 \mathrm{mg} / \mathrm{kg}$. Signs of acute toxicity in animals included ataxia, labored breathing, ptosis, sedation, hypoactivity, or excitation. Acute oral overdoses of Netriontin up to 49 grams have been reported. In these cases, double vision, slurred speech, drowsiness, lethargy and diarthea were observed. All patients recovered with supportive care. Gabapentin can be removed by the patient's clinical state or in patients with significant renal impairment.

Neuronti ${ }^{3}$ is recommended for add-on therapy in patients 3 years of age and older. Effectiveness in pediatric patients below the age of 3 years has not been established. Neurontin is given orally with or without food. Patlents >12 Years of Age: The effective dose of Neurontin is 900 to $1800 \mathrm{mg} /$ day and given in divided doses (three times a day) using

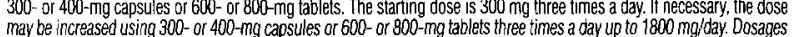
may be increased using 300 -or 400 -mg capsules or 600 -or 800 -ma tablets three times a day up to 1800 mg/day. Dosages up to $2400 \mathrm{mg} /$ day have been well tolerated in long-term clinical studies. Doses of $3600 \mathrm{mg} /$ cay have also been administered to a smail number of patients for a relatively short duration, and have been well tolerated. The maximum dose should range from $10-15 \mathrm{mg} / \mathrm{kg} / \mathrm{day}$ in 3 divided doses, and the effective dose raached by upward titration over a period of approximately 3 days. The effective dose of Neurontin in patients 5 years of age and older is $25-35 \mathrm{mg} / \mathrm{kg} / \mathrm{day}$ period of approximately 3 days. The eftective dose of Neurontin in patients 5 years of age and older is $25-35 \mathrm{mg} / \mathrm{kg} / \mathrm{day}$ and given in divided doses (three times a day). The effective dose in pediatric patients ages 3 and 4 years is $40 \mathrm{mg} / \mathrm{kg} / \mathrm{day}$ administered as the oral solution, capsule or tabiet, or using combinations of these formulations. Dosages up to $50 \mathrm{mg} / \mathrm{kg} / d a y$ have been well tolerated in a long-term clinical study. The maximum time interval between doses should not exceed 12 hours, It is not necessary to monitor cabapentin plasma concentrations to optimize Neurontin therapy. Further, because there are no significant pharmacokinetic interactions among Neurontin ${ }^{s}$ and other commonly used antiepileptic orugs, the addition of Neurontin $n^{*}$ does not alter the plasma leveis of these drugs appreciably. If Neurontin is discontinued and/or an alternate anticonuulsant medication is added to the therapy this should be done gradually over a minimum of 1 week. Creatinine clearance is difficult to measure in outpatients ln patients with stable renal lunction, creatin ine clearance ( $C \mathrm{C}$ ) can be reasonably weil estimated using the equation of Cockcrott and Gautt:

for females $\quad C_{C r}=(0.85)\left(140\right.$-age)(weight) $\left./(72)\left(\mathrm{SCC}_{\mathrm{C}}\right)\right]$

for males $\quad \mathrm{C}_{\mathrm{Cr}}=\left(140\right.$-age) $($ weight $) /(72)\left(\mathrm{SCr}_{2}\right)$

where age is in years, weight is in kilograms and $\mathrm{Scr}$ is serum creatinine in mg/d. Dosage adjustment in patients $\geq 12$ years of age with compromised renal function or undergoing hemodialysis is recommended as tollows:

TABLE 3. Neurontin Dosage Based on Renal Function

\begin{tabular}{ccc}
$\begin{array}{c}\text { Renal Function } \\
\text { Creatinine Clearance } \\
(\mathrm{mL} / \mathrm{min})\end{array}$ & $\begin{array}{c}\text { Total Daily Dose } \\
\text { (mig/day) }\end{array}$ & $\begin{array}{c}\text { Dose Regimen } \\
\text { (mg) }\end{array}$ \\
\hline$>60$ & 1200 & $400 \mathrm{T.LD}$. \\
$30-60$ & 600 & $300 \mathrm{~B} .1 . \mathrm{D}$ \\
$15-30$ & 300 & 3000.0. \\
$<15$ & 150 & $3000.0 . \mathrm{D}$. \\
Hemodialysis & - & $200-300^{\circ}$ \\
\hline
\end{tabular}

"Every other day. "Loading dose of 300 to $400 \mathrm{mg}$ in oalients who have never received Neuronti ${ }^{3 "}$, then 200 to $300 \mathrm{mg}$ Neurontin" lollowing each 4 hou's of hemodialysis.

The use of Neurontin" in patients <12 years of age with compromised renal function has not been studied.

Rx only

\section{Distributed by:}

\section{PARKE-DAVIS}

A Pfizer Company

(C)1999, PDPL Rev. 0 , Jully 200

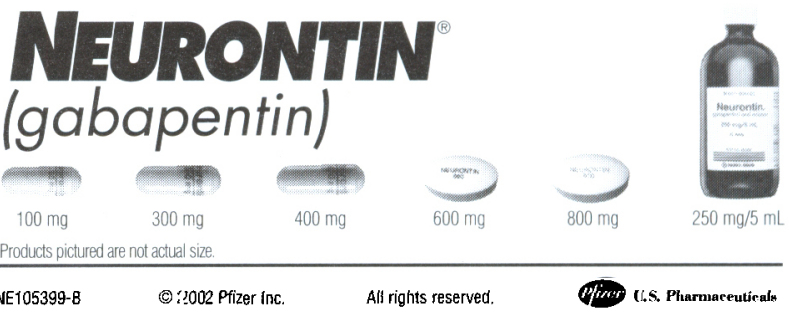




\section{NEURONTIN⿴囗十 (gabapentin) capsules \\ NEURONTIN ${ }^{\circledR}$ (gabapentin) tablets}

NEURONTIN (gabapentin) oral solution

Before prescribing, please see full prescribing information. A Brief Surmmary follows.

INDICATIOHS AND USAGE

Neurontin (gabapentin) is indicated as adjunctive therapy in the treatment of partial seizures with and without secondary generalization in patients over 12 vears of age with eplepsy. Neurontin is also indicated as adjunctive therapy in the treatment of partial seizures in pediatric patients age 3-12 years.

CONTRAINDICATIONS

Neurontin is contraindicated in patients who have demonstzated hypersensitivity to the drug or its ingredients WARNBHGS

Neuropsychiatric Adverse Events-Pediatric Patients 3-12 Years of Age Gabapentin use in pediatric patients problems), 2 ? hostility, including agiressive behaviors, 3) thought disorder, incleding corcentration problems and change in school performance, and 4) hyperkinesia (primarily restlessness and hyperactivity). Among the gabapentintreated patients, most of the events were mild to moderate in intensity. In controlled trials in peciatric patients 3-12 years of age the incidence of these adverse events was: emotional lability $6 \%$ (gabapentin-treated patientis) vs $1.3 \%$ (placebotreated patients); hostility $5.2 \%$ vs $1.3 \%$; hyperkinesia $4.7 \%$ vs $2.9 \%$; and thought disorder $1.7 \%$ vs $0 \%$. One of these events, a report of hostility, was considered serious. Discontinuation of gabapentin treatment occurred in $1.3 \%$ of patients reporting emotional lability and hyperkinesia and $0.9 \%$ of gabapentin-treated patients reporting hostility and though disorder. One placebo-traated patient $(0.4 \%)$ withdrew due to emotional lability. Withdrawal Precipitated Soizure, Status Epilepticus Antiepileptic drugs should not be abruptly discontinued because of the possibility of increasing seizure frequency. In the placebo-controlled studies in patients $>12$ years of age, the incidence of status epilepticus in patients receiving Neurontin ${ }^{3}$ was $0.6 \%$ ( 3 of 543 ) versus $0.5 \%$ in patients receiving placebo (2 of 378 ). Among the 2074 patients treated with Neurontin $n^{\mathrm{E}}$ across all studies (controlled and uncontrolled) $31(1.5 \%)$ had status epilepticus. Of these, 14 patients had no prior history of status epilepticus either before treatment or while on other medications. Because adequate historical data are not available, it is impossible to say whether or not treatment with Neurontin in associated with a higher or lower rate of status epilepticus than would be expected to occur in a similar population no treated with Neurontin . Tumorigenic Potential In standard preclinical in vivo lifetime carcinogenicity studies, an unexpectedly high incidence of pancreatic acinar adenocarcinomas was identified in male, but not female, rats. (See PRECAUUTIONS: Carcinogenesis, Mutagenesis, Impairment of Fertility.) The clinical significance of this tinding is unknown. Clinical experience during gabapentin's premarketing development provides no direct means to assess its potential for inducing tumors in humans. In clinical studies comprising 2085 patient-years of exposure, new tumors were reported in 10 patients (2 breast, 3 brain, 2 lung, 1 adrenal, 1 non-Hodgkin's lymphoma, 1 endometrial carcinoma in situ), and preexisting tumors worsened in 11 patients ( 9 brain, 1 breast, 1 prostate) during or up to 2 years following discontinuation of Neurontin ${ }^{\circ}$. Without knowledge of the backgrcund incidence and recurrence in a similar population not treated with Neurontints it is impossible to know whether the incidence seen in this cohort is of is not affected by treatrment. Sudden and Unexplained Deaths During the course of premarketing development of Neurontin ${ }^{\circ}$, sudden and unexplained deaths were recorded among a cohort of 2203 patients treated (2103 patient-years of exposure). Some of these could represent seizure-related deaths in which the seizure was not observed, e.g., at night. This represents an incidence of 0.0038 deahs per patient-year. Although this rate exceeds that expected in a healthy population matched tor age and Sex, it is within the range of estimates for the incidence of sudden unexplained deaths in patients with epilepsy not receiving Neurontin (ranging from 0.0005 for the general population of epileptics, to 0.003 for a clinical trial population similar to reassuring or raise further concern depends on comparability of the populations repoted upon to the Neurontin ${ }^{\circ}$ conort reassuring or raise further concenn depends on

\section{PRECAUTIONS}

Inlormation for Patients Patients should be instructed to take Neurontine only as prescribed. Patients should be advised hat Neurontin may cause diziness, somnolence ano oner symptoms and signs of CNS depression Accordingly they should be advised neither to drive a car nor to operate other complex machinery until they have ga ined sufficient expetience on Neurontin's to gauge whether or not it affects their mental and/or motor performlance adversely. Laboratory Tests Clinical trials data do not indicate that routine monitoring of clinical lacoratory parameter's is necessary for the sale use o

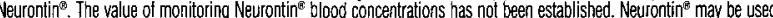
other antiepileptic drugs. Drug Interactions Gabapentin is not appreciably metabolized nor does it interfere with the metabo ism of commonly coadministered antlepileotic drugs. The drug interacion data described in this section were cotained from studies involving heal hy adults and adult patients with ep lepsy. Phenytoin: In a single and multiple dose

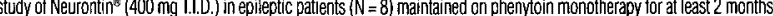
gabapentin had no elect on the sleady-state trought plasma conceniliations of phenytoin and phenytoin had no eftect on gabapentin pharmacokinefics Carbamazepine: Steady-state trough plasma carbamazepine and carbamazepine 10 11 epoxide concentrations were not aftected by concomitant gabapentin (400 ma T.L.D.: N=12) administration. Likewise gabapentin pharmacokinetics were unalered by carbamazepine administration. Vaiproic Acid: The mean steady-stale rough serum valproic acid concentrations prior to and during concomitant gabapentin administration (400 mig T.I.D.: N=17) were not different and neither were gabapentin pharmacokinetic parameters affected by valproic acid. Phenobarbital Estimates of steady-state pharmacokinetic parameters for phenobarbital or gabapentin (300 mg T.I. D. $\mathrm{N}=12$ ) are identica whether the drugs are administered alone or together. Cimetidine: In the presence of cimetidine at $300 \mathrm{mo} Q .1 .0$. (N=12) the mean apparent oral clearance of gabapentin fell by $14 \%$ and creatinine clearance fell by $10 \%$. Thus cimetidine appeared to alter the renal excrestion of both gabapentin and creatinine, an endogenous marker of renal function. This smal decrease in excretion of gabapentin by cimetidine is not expected to te of clinical importance. The effect of gabajentin on cimetidine was not evaluated. Oral Contraceptive: Based on AuC and hali-lite, multipie-dose pharmacokinetic profiles of norethindrone and ethinyl estradiol following administration of tablets containing $2.5 \mathrm{mg}$ of norethindrone acetate and $50 \mathrm{mcg}$ of ethinyl estradiol were similar with and without coadministration of gabapentin ( $400 \mathrm{mg}$ T.I.D: $: \mathrm{N}=13$ ). The $\mathrm{Cmax}$ norethindrone wa $13 \%$ higher when it was coadministered with gatapent this interaction is not expected to be o clinical importance. Antacid (Maalox): Maalox reduced the bioavailability of gabapentin $(N=16)$ by about $20 \%$. This decrease in bioavalability was about $5 \%$ when nabapentin was administered 2 hours atter Maalox. It is recommended that gabapentin be taken at least 2 hours following Maalox administration. Eflect of Probenecid: Probenecid is a blocker o renal tubular secretion, Gabapentin pharmacokinetic parameters without and with probenecid were comparable. This indicates that gabapentin does not undergo renal tubular secretion by the pathway that is blocked by probenecid Drug/Laboratory Tests Interactions Because false positive readings were reported with the Ames $N$-Multistix $S G^{\text {D }}$ dipstick test for urinary protein when gabapentin was added to other antiepileptic drugs, the more specific sulfosalicylic acic precipitation procedure is recommended to deternine the presence of urine protein. Carcinogenesis, Mutagenesis, mpairment of Fortility Gabapentin was given in the diet to mice at 200,600 , and $2000 \mathrm{mg} / \mathrm{kg} / \mathrm{day}$ and to rats at 250 , 1000 , and $2000 \mathrm{mg} / \mathrm{kg} / \mathrm{day}$ for 2 years. A statistically significant increase in the incidence of pancreatic acinar cell adenomas and carcinomas was found in male rats receiving the high oose; the no-effect dose for the occurrence of carcinomas was $000 \mathrm{mg} / \mathrm{kg} /$ day. Peak plasma concentrations of gabapentin in rats receiving the high dose of $2000 \mathrm{mg} / \mathrm{kg}$ were 10 times higher than plasma concentrations in humans receiving $3600 \mathrm{mg}$ per day, and in rats receiving $1000 \mathrm{mg} / \mathrm{kg} / \mathrm{day}$ peak plasma concentrations were 6.5 times higher than in humans receiving $3600 \mathrm{mg} /$ day. The pancreatic acinar cell carcinomas did not affect survival, did not metastasize and were not locally invasive. The relevance of this finding to carcinogenic risk in humans is unclear. Studies designed to investigate the mechanism of gabapentin-induced pancieatic carcinogenesis in rats indicate that gabapentin stimulates DNA synthesis in rat pancreatic acinar cells in vitro and, thus, may be acting as a tumor promoter by enhancing mitogenic activity. It is not known whether gabapentin has the ability to increase cell proitiferation in other cell types or in other species, including humans. Gabapentin did not demonstrate mutagenic or genotoxic potential in three in vitro and four in vivo assays. It was negative in the Ames test and the in vitro HGPRT forward mutation assay in Chinese hamster lung cells; it did not produce significant increases in chromosomal aberrations in the in vitro Chinese hamster lung cell assay, it was negative in the in vivo chromosomal aberration assay and in the in vivo microntcleus test in Chinese hamster bone marrow, it was negative in the in vivo mouse micronucleus assay, and it did fot induce unscheduled DNA synthesis in hepatocytes trom rats given gabapentin. No adverse effects on fertility or reproduction were observed in rats at doses up to $2000 \mathrm{mg} / \mathrm{kg}$ (approximately 5 times the maximum recommended human dose on an $\mathrm{mg} / \mathrm{m}^{2}$ basis). Pregnancy Pregnancy Category $\mathrm{C}$ : Gabapentin has been shown to be fetotoxic in rodents, causing delayed ossification of several bones in the skull, vertebrae, forelimbs, and hindlimbs. These effects occurred when pregnant mice received oral doses of 1000 or $3000 \mathrm{mg} / \mathrm{kg} / \mathrm{day}$ during the period of organogenesis, of approximately 11 to 4 times the maximum dose of $3600 \mathrm{mg} / \mathrm{day}$ given to epileptic patients on a $\mathrm{mg} / \mathrm{m}^{2}$ basis. The no-effect level was $500 \mathrm{mg} / \mathrm{kg} / \mathrm{oay}$ or approximately $1 / 2$ of the human dose on a $\mathrm{mg}^{\prime} \mathrm{m}^{2}$ basis. When rats were dosed prior to and during mating, and throughout gestation, pups from all dose groups $\{500,1000$ and $2000 \mathrm{mg} / \mathrm{kg} / \mathrm{day}$ ) were affected. These doses are equivalent b less than approximately 105 imes the maximum human dose on a mg $/ \mathrm{m}^{2}$ basis. There was an increased incidence of hydroureter and/or hydronephrosis in rats in a siudy of fertility and general reproductive periormance at $2000 \mathrm{mg} / \mathrm{kg} / \mathrm{day}$ with no eflect at $1000 \mathrm{mg} / \mathrm{kg} / \mathrm{day}$, in a teratology study at $1500 \mathrm{mg} / \mathrm{kg} / \mathrm{day}$ with no effect at $300 \mathrm{mg} / \mathrm{kg} / \mathrm{day}$,

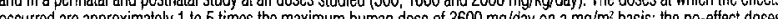

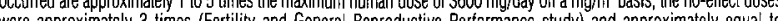
were approximately 3 times (Fertily and General Reproductive Pertormance study) and approximately equal to (Teratogenicity study) the maximum human dose on a mig/mith basis. Other than hydrouleter and hydronephrosis, the ellologles of which are unclear, the incidence ot mallormations was not increased compared lo controls in on sp: ing dose on a mo/kg basis, or 4 times (mice), 5 times (rats), or 8 times (rabbits), the human daily dose on a mo/m² basis. 


\section{a 8 .}




\section{STRONG SILENT TYPE. LIKE HIS NEURONTIN.}

\section{ADD-ON PARTIAL-SEIZURE CONTROL WITH EXCELLENT TOLERABILITY}

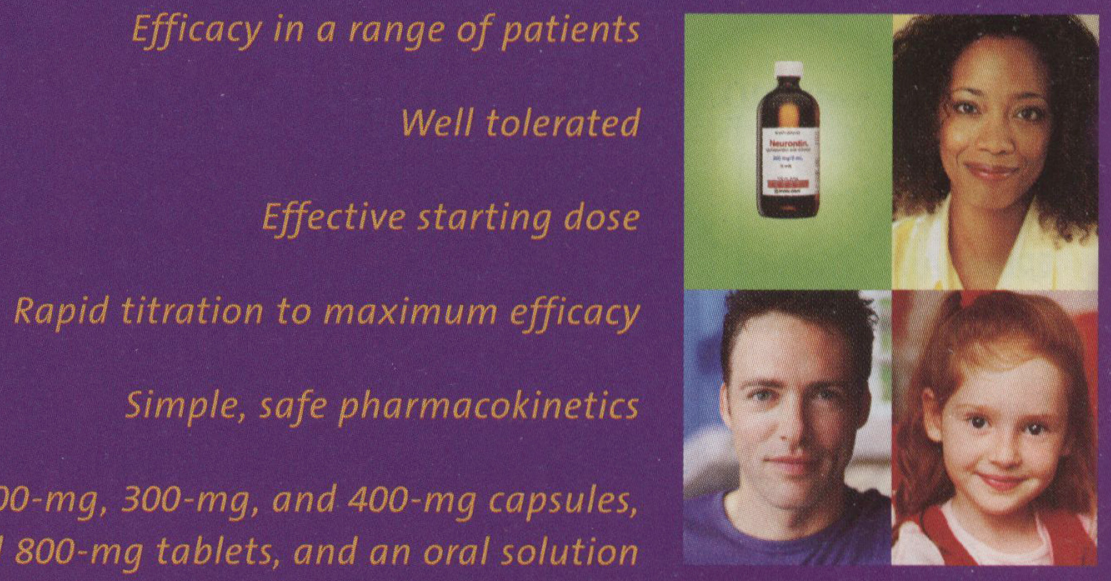

NEURONTIN is indicated as adjunctive treatment for partial seizures in pediatric patients (3-12 years old) and for partial seizures with and without secondary generalization in adults ( $>12$ years old). NEURONTIN is contraindicated in patients who have demonstrated hypersensitivity to the drug or its ingredients. NEURONTIN use in pediatric patients aged 3 to 12 years has been associated with mild to moderate neuropsychiatric adverse events, including emotional lability, hostility, thought disorder, and hyperkinesia.

In controlled clinical trials, the most common adverse events reported with NEURONTIN vs placebo in adults ( $>12$ years old) were somnolence ( $19.3 \%$ vs $8.7 \%$ ), dizziness $(17.1 \%$ vs $6.9 \%)$, ataxia ( $12.5 \%$ vs $5.6 \%)$, fatigue $(11.0 \%$ vs $5.0 \%)$, and nystagmus $(8.3 \%$ vs $4.0 \%$ ); the most common adverse events in pediatric patients ( $3-12$ years old) were viral infection $(10.9 \%$ vs $3.1 \%$ ), fever $(10.1 \%$ vs $3.1 \%)$, nausea and/or vomiting (8.4\% vs $7.0 \%)$, somnolence (8.4\% vs $4.7 \%)$, and hostility $(7.6 \%$ vs $2.3 \%)$. 


\section{$\overline{\mathrm{CNS} \mathrm{SPECTRUMS}}^{\circ}$}

The International Journal of Neuropsychiatric Medicine

\section{EDITOR}

Jack M. Gorman, MD

Mt. Sinai School of Medicine

New York, NY

\section{INTERNATIONAL EDITOR}

Joseph Zohar, MD

Chaim Sheba Medical Center

Tel Hashomer, Israel

\section{ASSOCIATE INTERNATIONAL EDITORS \\ EUROPE}

Donatella Marazziti, MD

University of Pisa

Pisa, Italy

\section{MID-ATLANTKC}

Dan J. Stein, MB

University of Stellenbosch

Tygerberg, South Africa

\section{FAR EAST}

Shigeto Yamawaki, MD, PhD

Hiroshima University School

of Medicine

Hiroshima, Japan

\section{FOUNDING EDITOR}

Eric Hollander, MD

\section{CONTRIBUTING WRITERS}

Ashok J. Bharucha, MD

Jeffrey S. Harman, PhD

Eric J. Lenze, MD

Lynn M. Martire, PhD

Cameron McFarland, BA

\section{BOARD OF ADVISORS}

Margaret Altemus, MD

Cornell University Medical Center New York, NY

Mitchell F. Brin, MD

Mount Sinai School of Medicine New York, NY

Dennis S. Charney, MD

Yale University

New Haven, CT

Jeffrey L. Cummings, MD

University of California

Los Angeles, CA

Dwight L. Evans, MD

University of Pennsylvania

Philadelphia, PA

Mark George, MD

Medical University of South Carolina Charleston, SC

Thomas R. Insel, MD

Yerkes Primate Labs

Emory University School of Medicine

Atlanta, GA

Lorrin M. Koran, MD

Stanford University Medical School Stanford, CA

Herbert Y. Meltzer, MD

Vanderbilt University Medical Center Nashville, TN

Stuart A. Montgomery, MD

St. Mary's Hospital Medical School

London, United Kingdom

Dennis L. Murphy, MD

National Institute of Mental Health Bethesda, MD
Charles B. Nemeroff, MD, PhD

Emory University School of Medicine Atlanta, GA

Humberto Nicolini, MD, PhD Instituto Mexicano de Psiquiatria Mexico City, Mexico

Katharine Phillips, MD

Brown University

Providence, RI

Harold A. Pincus, MD

Western Psychiatric Institute \& Clinic RAND-University of Pittsburgh Health Institute, Pittsburgh, PA

Scott L. Rauch, MD

Massachusetts General Hospital

Charlestown, MA

Alan Schatzberg, MD

Stanford University Medical School

Stanford, CA

Norman Sussman, MD

New York University Medical School

New York, NY

Neal R. Swerdlow, MD, PhD

University of California, San Diego

La Jolla, CA

Michael Trimble, MD

National Hospital for Neurology

and Neurosurgery

London, United Kingdom

Karen Wagner, MD

University of Texas

Galveston, Tex

Herman G.M. Westenberg, MD

University Hospital Utrecht

Utrecht, The Netherlands

Stuart Yudofsky, MD

Baylor College of Medicine

Houston, TX

MBL COMMUNICATIONS, INC

\begin{tabular}{l}
\hline CEO \&. PUBLISHER \\
Darren L. Brodeur \\
MANAGING EDITOR \\
Christopher Naccari \\
SENIOR EDITOR \\
Deborah Hughes \\
DEPUTY SENIOR EDITOR \\
José R. Ralat \\
ACQUISITIONS EDITOR \\
Lisa Arrington \\
GRAPHIC DESIGNER \\
Anthony J. Korsak
\end{tabular}

PRODUCTION MANAGER

Lila Moses

DESIGNER, MULTIMEDIA

Michael Mosley

CONTROLLER

John Spano

SENIOR ACCOUNT MANAGER

Robert Reed

ADMINISTRATIVE ASSISTANT

Claudette Crawford
OFFICE ASSISTANT

Manuel Pavón

INFORMATION TECHNOLOGY

Adam Bolt

CORPORATION COUNSEL

Kevin F. Saer, Esq.

Davis, Wright, and Tremaine

OF COUNSEL

Lawrence Ross, Esq.

Bressler, Amery, and Ross

CNS Spectrums' editorial mission is to address relevant neuropsychiatric topics, including the prevalence of comorbid diseases among patients, and reports that emphasize the profound diagnostic and physiologic connections made within the neurologic and psychiatric fields. It serves as a resource to psychiatrists and neurologists seeking to understand and treat disturbances of cognition, emotion, and behavior as a direct consequence of centeral nervous system disease, illness, or trauma. 


\section{BRIEF SUMMARY Of PRESCRIBING WNFORMATTON}

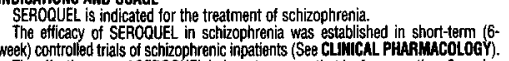
Whe effectiveness of SEROOUELL in long-term use, that is, for more than 6 weeks, has not been systematically evaluated in controlled trials. Therefore, the physician
who elects to use SEROOUEL for extended period's should periodically re-evaluate

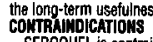

SEROQUEL is contraindicated in individuals with a known hypersansitivity to this
madication or any of its ingredients. maAMIMGS or any of its ingredients.

Mauroleptlc Mallgnant Syndrome: (MWS) A potentially fatal symptom complex

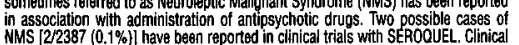
manifestations of NMS are hyperpyrexia, muscle rigidity, attered mental status, and evidence of autonomic instability (iireegular pulse or bilood pressure, tachycardia, phosphokinase, myoglobinuria (thabdomyolysis) and acute renal tailure. The diag-
nostic evaluation of patients with this syndrome is complicated. In amiving at a diannosis, it is impontant to exclude cases where the clinical presentation includes
both serious medical illnoss (8.9., pneumonia. systemic infection, etc.) and untreated or inadequately treated extrapyramidal signs and symptoms (EPS). Other important
considderations in the differential diagnosis include central anticholinergic toxictity, heat stroke, drutg fever and primary central nervous system (CNS) pathology. The
management of fuMS should include: 1) immediate discontinuation of antipsychotic

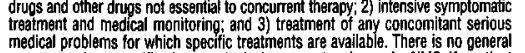
medical problems for which specific treatments are avalable. There is no general
agreement about specicic pharmacological treatment regimens for NMS . If a patient
requires antipsychotic drug treatment after recovery from NMS, the potential reinrequires antipsychotic drug treatment atter recovery from M. Th, Ihe potentlal rein-
troduction of drug therapy should be carefully considered. The patient should be

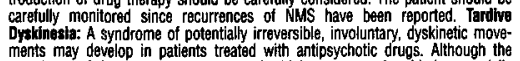
ments may develop in patients treated with antipsychotic drugs. Although the
prevalence of the syndrame appears to be highest among the elderty, especially
elderly women, it is impossible to rely upon prevalence estimates to prediot, at the inception of antipsychotic treatment, which patients are likely to develop the syndrome. Whether ancipsychotic drug products difier in their potential to cause tarcive
dyskinesia is unitnown. The risk of developing tardive dyskinesia and the likelihood that It will become irreversible are believed to increase as the duration of treatment
and the total cumulative dose of antipsychotic drugs administered to the patient increase. However, the syndrome can develop, although much lass commondy, after
relatively brief treatment periods at low doses. There is no known treatment for enstablished cases of tardive dyskinesia, although the syndrome may remit, partially
or completely, if antiosychoutc treatment is withdrawn. Antipsychotic treatment, itself, however, may suppress (or partially suppress) the signs and symptoms of the
syndrome and thereby may possibly mask the underlying process. The effect that symptomatic suppression has upon the long-term course of the syndrome is
unknown. Given these considerations, SEROouteL should be prescribed in a manner that is most likely to minimize the occurrence of tardive dyskinesia. Chronic antipsy-
chotic treatment should generally be reserved for patients who appear to strfter from a chronic illness that (1) is known to respond to antipsychotic drugs, and (2) for
whom alternative, equally effective, but potentially less harmful treatments are not availabie or appropriate. In patients who do require chronic treatment. the smallest
dose and the shortest duration of treatment producing a satisfactory clinical dose and the shortest duration of treatment producing a satisfactory clinical
response shoully be sought. The need for continued treatment should be reassessed
periodically. If signs and symptoms of tardive dyskinesia appear in a patient on periodically. If signs and symptoms of tardive dyskinesia appear in a patient on
SEROQUEC, drug discontinuation should be considered. However, some patients may require tratiment with SERODUEL despite the presence of the syndrome.
PRECAUTIONS: General

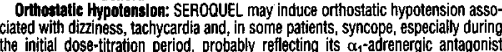

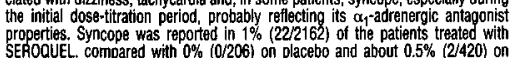
active control drues. The risk of orthostatic hypotansion and syncope may be
minimized by limiting the initial dose to $25 \mathrm{mg}$ bid. If hypotension occurs during titration to the target dose a return to the previous dose in the titration schedule
is appropriate. SERKOQUEL should be used with particular caution in patients with disease, heart tailure or conduction abnormalitiess), cerebrovascular disease or con-

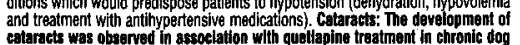
catariects was observed in association with quedlapine traatment in chronitic dog

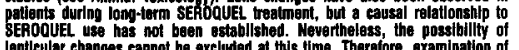

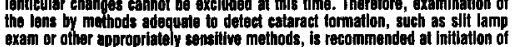

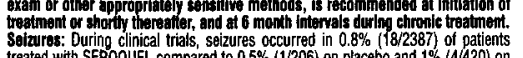

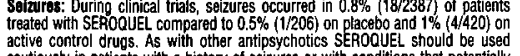
cautiousty in patients with a history of seizures or with conditions that potentially
lower the seizure thresholdt, e.g., Alzheimer's dementia. Conditions that lower the seizure threshold may be more prevalent in a population of 65 years or older.
Hypothyroidism: Clinical trials with SEROCUEL demonstrated a dosa-related decrease in total and free thyroxine (T4) of approximately $20 \%$ at the higher end of
the therapeutic doss rance and was maximal in the first two to four weeks of freatment and maintained without adaptation or progression during more chronic therapy. in most patients, and levels of TBG were unchanged. In nisarly all cases, cessation tree T4, irrespective of the duration of treatment. About $0.4 \%$ (10/2386) of
SEROQUEL patients did experience TSH increases. Six of the patients with TSH
increases needed replacement thyroid treatment. Chotesterol and Triglyceride increases needed replacement thyroid treatment. Cholesterol and Triglyceride
Elavaltions: In a pool of 3 - to 6-weak placebo-controlled trials, SEROoute-treated
patients had lincreases trom baseline in cholesterol and triglyceride of $11 \%$ and

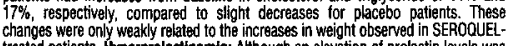
cheated patients. Ayperprolatilinemia: Athough an elevation of prolactin levels was
not demonstrated in clinical trials with SEROQUUE, increased prolactin levels were observed in rat studies with this compound, and were associated with an increase ments indicate that approximately one-third of human breast cancers are prolactin dependent in vitro, a tactor of potential importance if the prescription of these drugs
is contemplated in a patient with previously detected breast cancer, Although
disturbances such as galactormea, amenorrhea, oynecomastia, and impotence

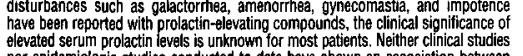
ter edidemiologic studilises conducted to date have shown an association between
chronic administration of this class of drugs and tumorigenesis in humans; the chronic administration of this class of drugs and tumorigenesis in humans, hime
available esvidence is considered too limited to be conclussve at this time.
Trangaminase Elevalions: Asymptomatic, transient and reversible elevations in serum transaminases (primarily ALT) have been reported. The proportions of
patients with transaminase elevations of $>3$ times the upper limits of the normal reference range in a pool of 3- to 6 -week placebo-controlled trials were approxi-
mately $6 \%$ for SEROQUUEL compared to $1 \%$ for placebo. These hepatic enzyme

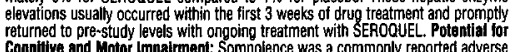
Cognitive and Motor Impaitment: Somnolence was a commonly reported adverse
event reported in patients treated with SEROQUEL especially during the $3-5$ day

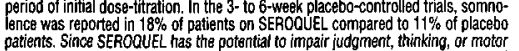
skills, patients should be cautioned about performing activities requiring mental
alertness, such as operating a motor vehicle (including automobiles) or operating hazardous machinery until they are reasonably certain that SEROQUUEL therapy
does not affect them adversely. Priapism: Ona case of priapism in a patient receiving SEROQUEL has been reportad prior to market introduction. While a causal relation-
ship to use of SEROOUEL, has not been established, other drugs with alpharadrenergic blocking effects have been reported to induce priapism, and it is surgical intervention. Body Tomperature Regulation: Although not reported with
SERCouluEL, dissuption of the body's ability to reduce core body temperature has been attributed to antipsychotic agents. Appropriate care is advised when prescribing
SEROOUEL. for patients who will be experiencing condititions which may contribute

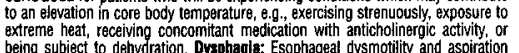

SEROCUEL (quetiapine fumarate) Tablets

have bsen associated with antipsychotic drug use. Aspiration pneumonia is a common cause of mortidity and mortality in elderly patients, in particulas those with
advanced Alaheimer's demmantia. SEROQUUE should be used cautiously in patients at risk for aspiration pneumonia. Surtecide: of high risk patients should accormpany drug therapy. Prescriptions for SEROQUEL should be written for the smallest quantity of tabiets consistent with good patient
management in order to reduce the risk of overdose. Use in Patlents with concomitant systernic illinesses is limited. SEROQUEEL has not been evaluaterd or used to any appreciable extent in patients with a recent history of myocardial infarc-
tion or unstable heart diseases. Patients with these diagnoses were excluded from premarketing clinical studies. Because of the risk of orthostatic hypotension with
SEROOUUEL, caution should be observed in cardiac patients see Orthostatic Hypotension). Intormation tor Patients: Physicians are advised to discuss the hypotension: Patients should be advised of the risk of orthostatic hypotension, especially during the $3-5$ day period of initial dose titration, and also at times of
re-initiating treatment or increases in dose. Intersterence with Cognitive and Motor with SEROQUEL treatment, patients should be advised of the risk of somnolence, especially during the $3-5$ day period of initial dose titration. Patients should be a motor vehicle (including automobies) or operating hazardous machinery, unti they are reasonatby certain that SEROQULEL therapy does not affect them adversely.

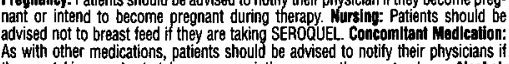
As with other medications, patients should be advised to notify their physicians
they are taking, or plan to take, any prescription or over-the-counter drugs. Alcohol: they are taking, or plan to take, any prescription or over-the-counter drugs. Alchich appropriate care in avoiding overheating and dehydration. Laboratory Tosts: No $S E R O Q U E L$
$S$ in combination with other drugs have not begn extensively evaluated in
systematic studies. Given the primary CNS effects of SEROOUEL, caution Stoulta be used when it is taken in combination with other centrally acting drugs. SEROQUEL

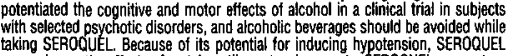
may enhance the effects of certain antihypertensive agents. SEROQUEL may antag.
onize the effects of levodopa and dopamine agonists. The Eflect of Other Drugs on SEROQUEL Phenytoin: Coadministration of quetiapine (250 mo tid) and phenyttoin (100 mo tidd increased the mean oral clearance of quetiapine by 5-fold. Increased
doses of SEROouEL may be required to maintain control of symptoms of schizo-
phrenia in patients receiving quetiapine and phenytoin, or other hepatic enzyme

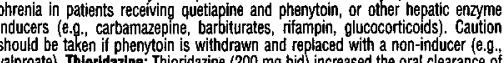
valproate). Thioridazine: Thioridazine (200 $\mathrm{mg}$ bid) increased the oral clearance of guetiapine (300 mg bid) by $65 \%$. CImetiteline: Administration of multiple daily

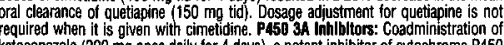
ketoconazole (200 mg once daily for 4 days), a potent inhibitor of cytochrome P450 $3 \mathrm{~A}$, reduced oral clearance of quetiapine by $84 \%$, resulting in a $335 \%$ increase in
maximum plasma concentration of quetiapine. Cautition is indicated when SEROQUEL
is admininistered with ketoconazole and other inhibitiors of cytochrome P450 $3 A$

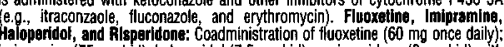
imipramine, $(75 \mathrm{mg}$ bid), haloperidol ( $7.5 \mathrm{mg}$ bid), or risperidone (3 $\mathrm{mg}$ bid) with
quetiapine $(300 \mathrm{mg}$ bid) did not alter the steady-state pharmacokinetics of

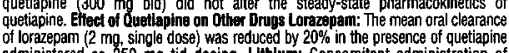
administered as $250 \mathrm{mg}$ tid dosing. Lithlum: Concomitant administration of quarmacokingtic parameters of lithium. Annllyyine: Administration of multipie daily doses up to $750 \mathrm{mg} / \mathrm{d}$ ay (on a tio schedule) of quetiapine to subjects with selected psychotic disordars had no clinically refevant effect on the clearance of antipyrine or
urfinary recovery of antipyrine metabolites. These results indicate that quetiapine

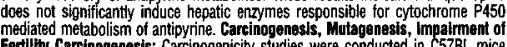

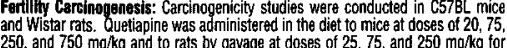
250 , and 750 mg/kg and to rats by gavage at doses of 25,75 , and $250 \mathrm{mg} / \mathrm{kg}$ for
two years. These doses are equivalent to $0.1,0.5,1.5$, and 4.5 times the maximum human dose (800 modday) on a mo/ $\mathrm{m}^{2}$ basis (mice) or $0.3,0.9$, and 3.0 times the
maximum human dose on a $\mathrm{mg} / \mathrm{m}^{2}$ basis (rats). There were statistically significant increases in thyroid gland follicular adesnomas in male mice at doses of 250 and 750 mojkg or 1.5 and 4.5 times the maximum human dose on a mger ${ }^{2}$ basis and
in male rats at a dose of $250 \mathrm{mg} / \mathrm{kg}$ or 3.0 times the maximum human dose on a

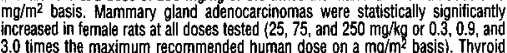
follicular cell adenomas may have resulted from chronic stimulation of the thyroid follicular cell adenomas may have rasulted from chronic stimulation of the thyroid
gland by thyyrod stimulating hormone (TSH) resulting from enhanced metabolism
and clearance of thyroxine by rodent liver. Changes in TSH, thyroxine, and thyroxine clearance consistent with this mechanism were observed in subchronic toxicity
studies in rat and mouse and in a t-year toxicity study in rat; however, the results these studies were not definitive. The relevance of the increases in thyyoid follicul cell adenomas to human risk, through whatever mecharism, is unknown.
Antipsychotic drugs have been shown to chronically elevate prolactin levels in rodents. Serum measurements in a 1-yr toxicity study showed that quetiapine emale rats, respectively. Increases in mamnanay neeplassms have been found in modiated mammary gland tumors in rats to human risk is unknown (se Hyperprolactinemia in PRECAUTIONS, Generall. Mutagenessis: Jhe mutagenic potential of quetiaine was tested in six in vitro bacterial gene mutation assays and
in an in vitro mammmalian gene mutation assay in Chinese Harnster Ovary colls. all tester strains. Quetiapine did produce a reproducible increase in mutations in one evidence of clastogenic potential was obtained in an in vitro chromosomamal aberration
assay in cultured human lymphocytes or in the in vivo micronucleus assay in rats. impairment of Fertlitty: Quetiapine decreased mating and fertility in male spragueDawley rats at oral doses of 50 and 150 mg/kg or 0.6 and 1.8 times the maximum human dose on a ma/m2 basis. Drug-related effects included increases in interval effects continued to be observed at 150 makke even after a two-week period withoul
treatment. The no-effect dose for impaired mating and fertility in male rats was

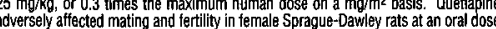
0150 mglkg, or 0.6 times the maximum human dose on a mo/m2 $\mathrm{m}^{2}$ basis. Drug-related
effects included decreases in matings and in matings resulting in pregnancy, and an increase in the interval to mate. An increase in irregular estrus cycles was observed
at doses of 10 and 50 mogkg, or 0.1 and 0.6 times the maximum human dose on a maximum human dose on a mg/m2 $\mathrm{m}^{2}$ basis. Pregnaney: Preghangey Category $\mathrm{C}$ : The toratogenic potential of quetiagine was studied in Wistar rats and Dutch Betied rabbits detected in rats at doses of $2510200 \mathrm{mg} / \mathrm{kg}$ or 0.3 to 2.4 times the maximum
hurnan dose on a molm $\mathrm{m}$ basis or in rabbits at 25 to $160 \mathrm{mg} / \mathrm{kg}$ or 0.6 to 2.4 times the embryoffetal toxicity. Deiays in skeletal ossifification were detected in rat fetuses at doses of 50 and $200 \mathrm{mg} / \mathrm{kg}$ ( 10.6 a and 2.4 times the maximum human dose on a
$\mathrm{mg}^{\prime} / \mathrm{m}^{2}$ basis) and in rabbits at 50 and $100 \mathrm{mg} / \mathrm{kg}$ (1.2 and 2.4 times the maximum human dose on a ma/m² basis\}. Fetal body weight was reduced in rat fetuses at on a mg/m² basis sor both species. There was an increased incidence of a minor
oft tissue anomaly (carpal/tarsas flexure) in rabboit fetusess at a dose of $100 \mathrm{~mm} / \mathrm{kg}$ (2.4 times the maximum humann dose on a ma/ $\mathrm{m}^{2}$ basis). Evidence of maternal toxduse in the rat study and at all doses in the rabbit study. In a peri/postnatal repro-

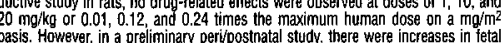
and pup death, and decreases in mean litter weight at $150 \mathrm{mg} / \mathrm{kg}$, or 3.0 times

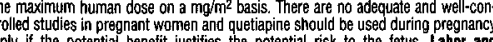
Only if the potential benefit justifies the potential risk to the fetus. Labor and
Dellwery: The effect of SEROQUUE on labor and delivery in humans is unknown.
SEROQUEL (quetiapine fumarate) Tablets

Mursing Mothers: SEROQUEL was excreted in milk of traated animals during lacta-
tion. It is not known if SEROOUU women receiving SEROQUEL should not braast fead. Peddatrie Use: The safoty and

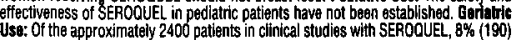
were 65 years of age of over. In general, there was no indication of any difierent
tolerability of SEROCUUEL in the elderly compared to younger adults. Nevertheless, the resence of factors that might decrease pharmacokingtic clearance, increase the pha macodynamic response to SEROQUEL, or cause poorer tolerances of orthostasis, monitoring during the intitial dosing period in the elderrit. The mean plasman clearance younger patients.

Adverse Events Decuuring at an Incidence of 1\% or Mors Anomo SEROQUEL observed adverse events associated with the use of SEROOUUEL (incidence of $5 \%$ of greater) and observed at a rate on SEROQUEE at least twice that of placabo were
dizziness (10\%), postural hypotension (7\%), dry mouth $(7 \%)$, and dyspepsia (6\%). of $1 \%$ or more, and were at least as frequent among SEROCUEL treated patients,
rreated at doses of 75 mog/day or greater than among placebo treated pationts in 3oty as a Whole: Headache, Asthenia, Abdominal pain, Back pain, Fever, Nervous Body as a Whole: Headache, Astheniza, Abdominal pain, Back pain, Fever, Nervous
System: Somnolence, Dizziness; Dloestive Syrtom: Constipation, Ory Mouth

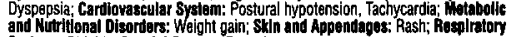
System: Ahinitis; \$peclai Senses: Ear pain
Eevents for which the SEROOUEL incidence was equal to or less than placebo are not listed in the table, but included the following: pain, infection, chest pain, hostility agltation, insomnia, anxiety nervousness, akathisia, hypartonia tremor, depresssion, parasthesia, pharyongitis, dry skin, amblyopia and urinary tract infoction.
Explorations for interactions on the basis of gender, age, and race dit not reveal any clinically meaningutul differencesces in the adverse event occurrence on the basis of thess

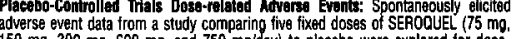

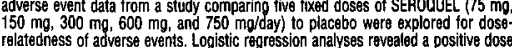

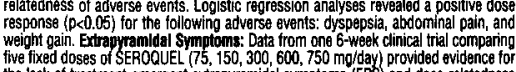

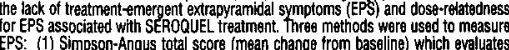
EPS: (1) Simpson-Angus total score (mean change from baseline) which evaluates
parkinsonism and akathisia. (2) incidence of spontaneous complaints of EPS parkinsonism and akathisia, (2) incidence of spontaneous complaints of
(akathisia, akinesia, cogwheal riglity. extrapyramidal syndrome, hypertonia, hypoki-

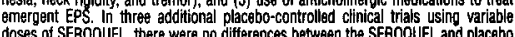
doses of SEROQUEL, there were no oifferencess between the SEFOOUEL and placebo
trraatment groups in the incidence of $E P S$, as assessed by Simpson-Angus total

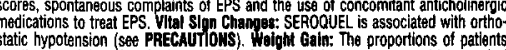

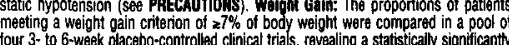
graater incidence of weight gain for SEROOUEL (23\%) Compared to placebo (6\%). suggested that it is associated with asymptomatic increases in SGP and increases in
both total cholesterol and trigycerides (soe PRECAUTIONS). An assossment of hema tological parameters in shorr-term, placebo-controlled trials revealed no clinically group comparisons for pooled placebo-controlled trials revealed no statistically potentially important changess in ECG parameters, includino QT, QTC, and PR intervals.

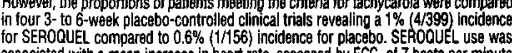
associated with a mean increase in heart rate, asssessed by ECG, of 7 baats per minute

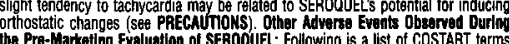

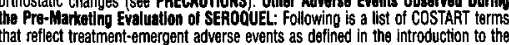
AOVERSE REACTIONS Section reported by patients treatind with SEROOUUEL at multiplo oses $₹ 75$ mo/day during any phase of a trial within the premarketing database of

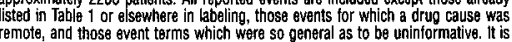
important to emphasize that, athough the events reported occurred turino treatment
with SEROQUUEL, they were not necessarily caused by ti. Events are further catoporized by body system and listed in ordar of dacraasing frequency according to the following (only those not already listed in the tabulated results from placebo-controlled trials

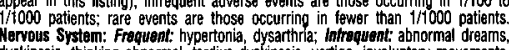

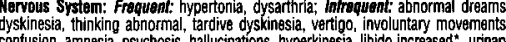

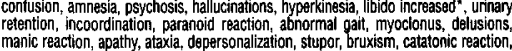
manic reaction, apathy, ataxia, depersonalization, stupor, bruxism, catatonic reaction,
herniplegia; Rare; aphasia, buccoglossal syndromg, choreazthetosis, delirium, emo-

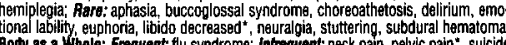

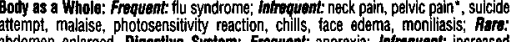

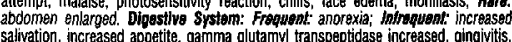

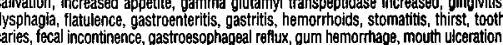
rectal hermorthage, tongue edema; Ruros glossitis, hematermessis, intestinal obstruction,

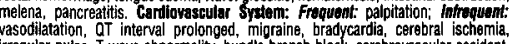

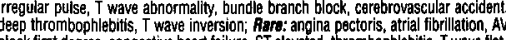

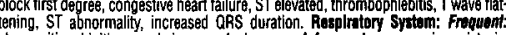

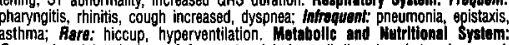
Frequent: peripheral edema; latrequent: weight loss, alkaline phosphatase increased,
hyperipemia, alcohol intolerance, dehydration, hyperglycemia, creatininine increased Skin and Appendages System: Frequent: sweating; infrequent: pruritis, acne,

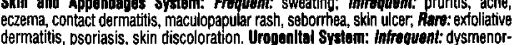

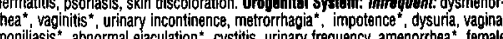

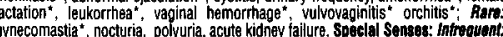

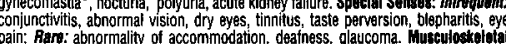

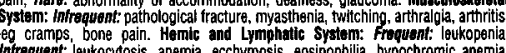

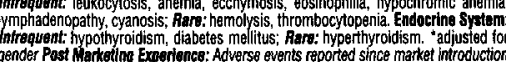

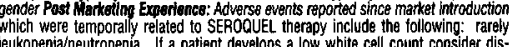
leukopenialneutropenia. If a patient develops a low white cell count consider dis-
continuation of therapy. Possible risk factors for leukopennia neutropenia include pre-existing low white coll count and history of drug induced leukopenia/neutropenia Controlled Substanes Class: SEROQUEL is not a controlled substance. 


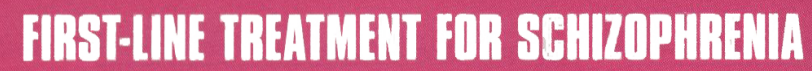

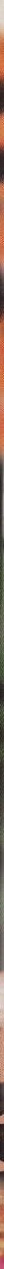

\section{WELI!}

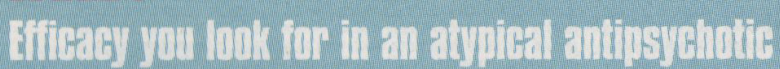

o Proven to reduce positive and negative symptoms ${ }^{14}$

\section{ABEEPTES!}

An ackellent silibafied profile

- The only first-line atypical antipsychotic with an EPS*

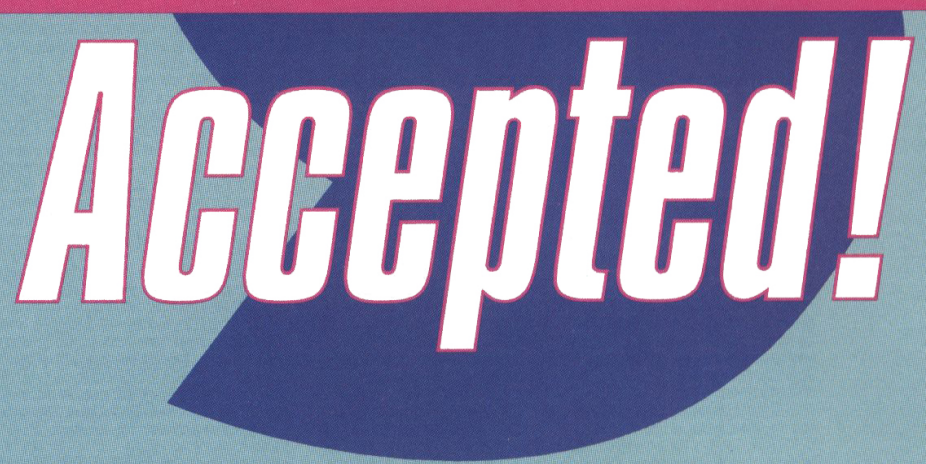

profile no different from placebo across the entire

dosing range (up to $800 \mathrm{mg}$ ).

*Extrapyramidai sympioms.

- The most common adverse events associated with the use of SEROQUEL are dizziness $(10 \%)$, postural hypotension $(7 \%)$, dry mouth $(7 \%)$, and dyspepsia $(6 \%)$. The majority of adverse events are mild or moderate

- As with all antipsychotic medications, prescribing should be consistent with the need to minimize the risk of tardive dyskinesia, seizures, and orthosiatic hypotension

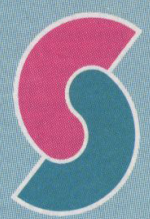

Seroquel quetiapine fumarate

$25 \mathrm{mg}, 100 \mathrm{mg}, 200 \mathrm{mg} \& 300 \mathrm{mg}$ tablets

References: 1. Small JG, Hirsch SR, Arvanitis LA, et al, and the Seroquel Study Group. Quetiapine in patients with schizophrenia: a high- and low-dose double-blind comparison with placebo. Arch Gen Psychiatry. 1997:54:549-557. 2. Arvanitis LA, Miller BG, and the SEROQUEL Trial 13 Study Group. Multiple fixed doses of "Seroquel" (quetiapine) in patients with acute exacerbation of schizophrenia: a comparison with haloperidol and placebo. Biol Psychiatry. 1997:42:233-246. 3. Borison RL, Avanitis LA, Miller BG. ICI 204,636, an atypical antipsychotic: efficacy and safety
in a multicenter, placebo-controlled trial in patients with schizophrenia. J Clin Psychopharmacol. 1996;16:158-169. 4. Data on file, Study S91, AstraZeneca Pharmaceuticals LP, Wilmington, Delaware. 5. SEROQUEL (quetiapine fumarate) Prescribing Information, Rev 1/01, AstraZeneca Pharmaceuticals LP, Wilmington, Delaware.

AstraZeneca

Astrazeneca Pharmaceuticals LP
C 2001 AstraZeneca Pharmaceuticals LP.

SEROQUEL is a registered trademark of the AstraZeneca group of companies

Please see Brief Summary of full Prescribing Information on following page.
WWW.SEROQUEL.COM

205337 


\section{Table of Contents}

Feature Articles

780 Introduction:

Geriatric Psychiatry: Challenges and Opportunities

By Benoit $\mathrm{H}$. Mulsant, MD

\section{ORIGINAL RESEARCH}

784 Primary Care Physicians' Attitude Toward Diagnosis and Treatment of Late-life Depression

By Jeffery S. Harman, PhD, Ellen L. Brown, EdD, MS, RN, Thomas Ten Have, PhD, Benoit H. Mulsant, MD, Greg Brown, MD, and Martha L. Bruce

\section{REVIEW}

791 Dementia Caregiving: Recent Research on Negative Health Effects and the Efficacy of Caregiver Interventions

By Lynn M. Martire, PhD, and Martica Hall, PhD

\section{REVIEW}

797 Assessment of Behavioral and

Psychological Symptoms of Dementia

By Ashok J. Bharucha, MD, Jules Rosen, MD,

Benoit H. Mulsant, MD, and Bruce G. Pollock, MD, PhD

\section{REVIEW}

805 Anxiety Disorders in Late Life:

An Evolving Picture

By Eric J. Lenze, MD, M. Katherine Shear, MD,

Benoit H. Mulsant, MD, and Charles F. Reynolds III, MD

\section{ORIGINAL RESEARCH}

816 The Establishment of a Brain Bank for the Study of Late-life Depression: A Feasibility Study of Factors Facilitating Consent

By Cameron McFarland, BA, Robert A. Sweet, MD, Steven T. DeKosky, MD, Patricia R. Houck, MSH, Benoit $\mathrm{H}$. Mulsant, MD, Bruce G. Pollock, MD, PhD, and Charles F. Reynolds III, MD

\begin{tabular}{c}
\hline CNS SPECTRUMS \\
\hline The International \\
Journal of \\
Neuropsychiatric \\
Medicine \\
volume 7 - Number 11 \\
November 2002 \\
\hline
\end{tabular}

CNS Spectrums is an Index Medicus journal and is available on MEDLINE. It is also indexed by DIALOG, EMBASE/Excerpta Medica, Lexis-Nexis, OVID, and SilverPlatter. CNS Spectrums is the official journal of the International Neuropsychiatric Association with members in 30 countries.

\section{CNS Spectrums}

(ISSN 1092-8529)

is published monthly by MBL Communications, Inc. 333 Hudson Street, 7th Floor New York, NY 10013

One year subscription rates: domestic \$120; foreign $\$ 185$; in-training $\$ 75$. For subscriptions: Fax 212-328-0600 or visit our Web site: www.cnsspectrums.com

Postmaster:

Send address changes to CNS Spectrums clo PPS Medical Marketing Group 264 Passaic Avenue Fairfield, NJ 07004-2595 


\section{CNS SPECTRLMS $^{\circ}$}

The International Journal of

Neuropsychiatric Medicine

Volume 7 - Number 11 November 2002

\section{Table of Contents}

Departments/Monthly Columns

\section{CNS DIGEST}

770 In the Journal of November 2002

Are Primary Care Physicians Prepared and Qualified to Diagnose and Treat Late-Life Depression?; Helping Caregivers Cope; Assessing The Symptoms of Dementia; A Better Understanding of Anxiety Disorders in the Elderly; How Easy is it to Establish a Brain Bank to Study Late-life Depression?

\section{CNS NEWS}

782 Briefs From the Fields of Neurology \& Neuropsychiatry Levetiracetam Shown to Reduce Seizure Frequency While Improving Quality of Life; Stroke Symptoms Differ From Sex to Sex; Dietary Intake of Vitamin E May Lead to Risk Reduction of Parkinson's Disease; Coils Lower Mortality and Disability From Brain Aneurysms; Antiepileptics May Induce Seizures; Request for Applications

\section{CONTINUING MEDICAL EDUCATION}

822 This Continuing Medical Education series gives the reader the opportunity to test his or her understanding and recall of clinical material presented in this issue. Approved for $\mathbf{3 . 0}$ credit hours in Category 1

\section{INDICES}

825 By subject and author

\section{TEACHING MONOGRAPH SUPPLEMENT}

The Use of Lithium in Treating Bipolar Disorder

By Frederick K. Goodwin, MD, Ross J. Baldessarini, MD, and David L. Dunner, MD

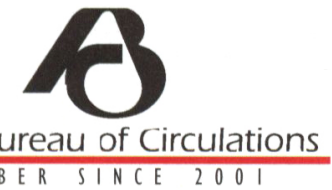

For editorial inquiries, please fax us at 212-328-0600 or e-mail us at jrr@mblcommunications.com.

For advertising inquires, please fax us at 212-328-0600 or e-mail us at dlb@mblcommunications.com.

Opinions and views expressed by authors are their own and do not necessarily reflect the views of the publisher,

MBL Communications, Inc., or the editorial advisory board. Advertisements in CNS Spectrums are accepted on the basis of adherence to ethical medical standards, but acceptance does not imply endorsement by CNS Spectrums or the publisher.

CNS Spectrums $\circledast$ is a registered trademark of CNS Spectrums, LLC, New York, NY.

Permission to reproduce articles in whole or part must be obtained in writing from the publisher.

Copyright $\odot 2002$ by MBL Communications, Inc. All rights reserved. Printed in the United States. 


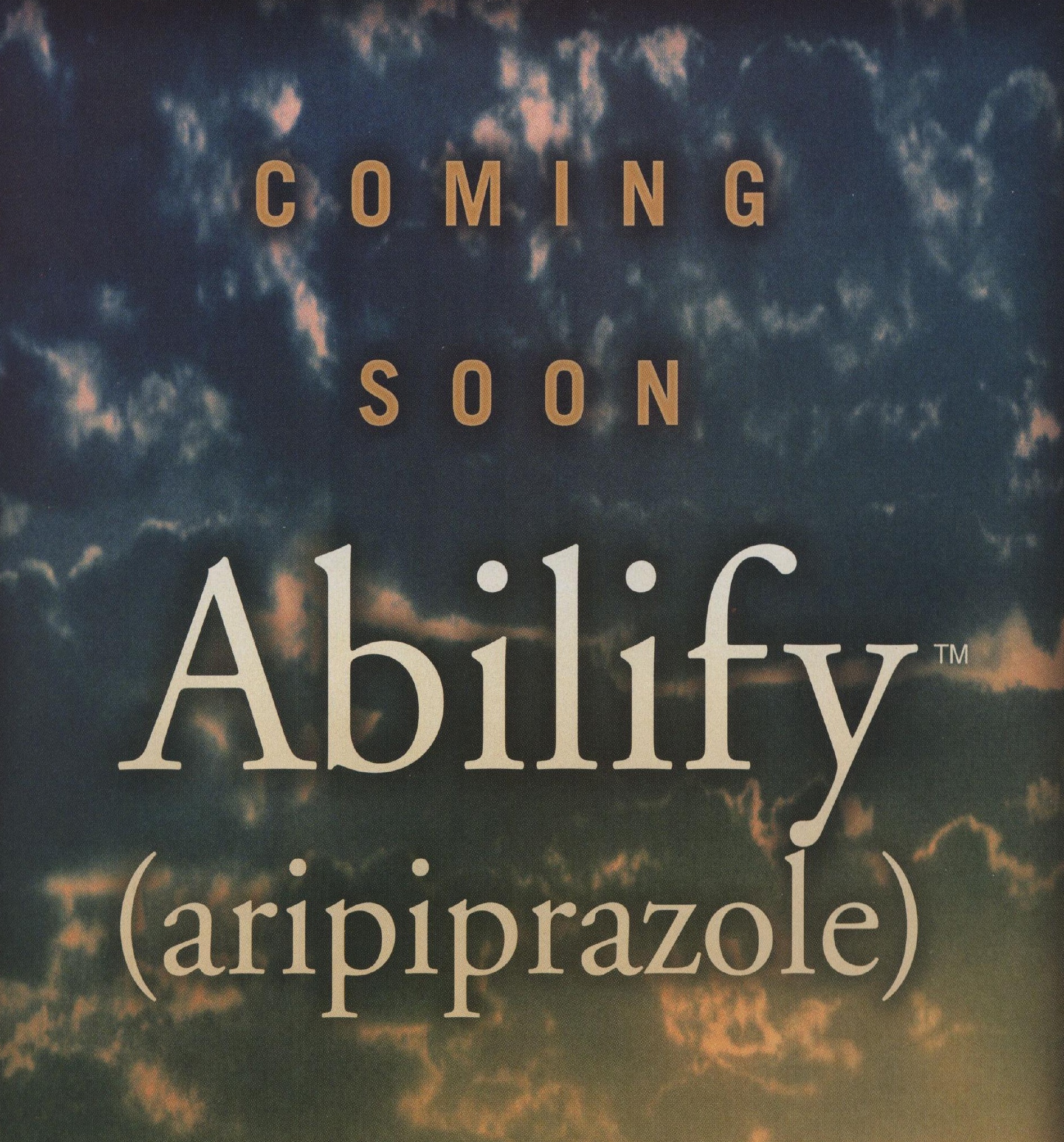

